\title{
Parathyroid Gland Follicle
}

National Cancer Institute

\section{Source}

National Cancer Institute. Parathyroid Gland Follicle. NCI Thesaurus. Code C33268.

A follicle believed to be formed by degeneration of suppressed chief cells. Secretion of hormonal and/or other substances into intercellular spaces prog ressively forms follicular cavities. 